Review Article

\title{
Antibiotic misuse and the development of bacterial resistance: Are we losing the battle?
}

\author{
Radhwan N. Al-Zidan ${ }^{1}$, Ghayth M Abdulrazzaq ${ }^{2}$, and Wejdan Al-Shakarchi ${ }^{3}$ \\ 1 Department of Pharmaceutics, 2 Department of Pharmacology, 3 Department of \\ Pharmaceutical Chemistry, College of Pharmacy, University of Mosul, Mosul, Iraq. \\ Radhwan.alzidan@uomosul.edu.iq
}

\begin{abstract}
$\underline{\text { Received }}$ Accepted
ABSTRACT

1.9.2019 1.12.2019
\end{abstract}

Objective: The present review targets to shed light on the crisis of developing the antibiotic resistance and specify the contemporary challenges associated with the misuse of the antibiotics.

Methods: The present challenges correlated to the development of the antibiotic resistance are distinctive and vary from the previous challenges because novel bacterial strains are continuously emerging and persist to evolve. Additionally, bacterial strains resistant to various antibiotic classes have arisen for which the use of recent antibiotics have not been reviewed thoroughly.

Results: The outcomes of antibiotic resistance are serious with morbidity and mortality incessantly on the rise. This review also underlines the feasible interventions that can be effective at the individual or micro level, as well as at the national or macro level in the prevention of antibiotic resistance.

Conclusion: To conclude, the rapid emergence of antibiotic-resistant bacteria threatens the astonishing health gains that have been attained since the invention of the antibiotic medications.

Keywords: Antibiotics Resistance, Self-medication, Antimicrobial Resistance, Antimicrobial Stewardship. 
سوء استخام المضادات الحيوية وتطور المقاومة البكتيرية: هل نحن نخسر المعركة؟ بحث مرجعي

الخلاصة

الغاية من الاراسة: تهدف المراجعة الحالية إلى تسليط الضوء على أزمة تطوير مقاومة الدضادات الحيوية

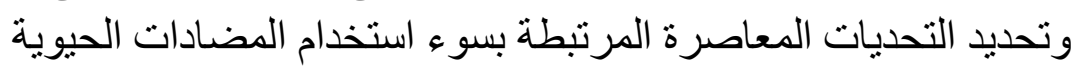

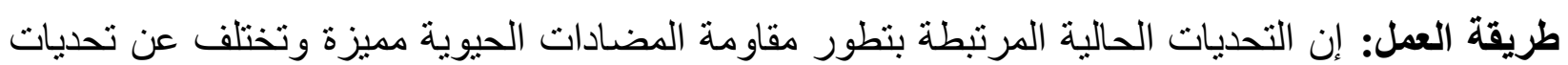

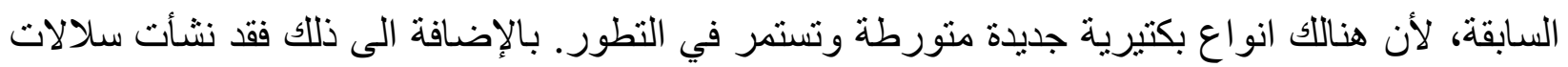

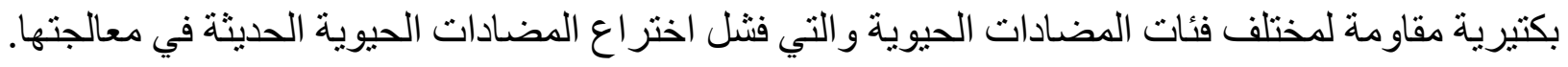

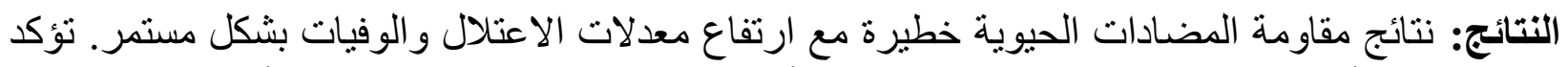

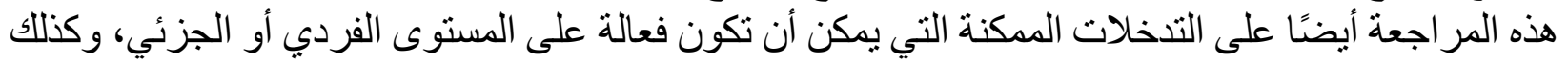

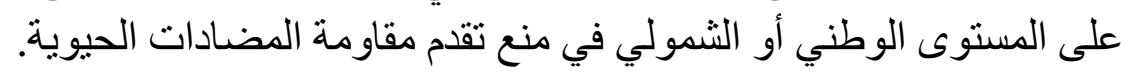

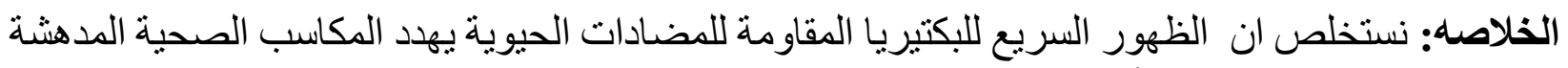
التي تم تحقيقها منذ اختر اع الأدوية الدضادة للمضادات الحئات الحيوية.

الكلمات المفتاحية: مقاومة المضادات الحيوية، التطبيب الذاتي، مقاومة مضادات الميكروبات، إدارة الدضادات

الحيوية

$\mathrm{P}$ rior to the invention of penicillin by Sir Alexander Fleming, in 1928, bacterial infections were the main cause of death in human. Before the penicillin time, a minor wound infection could develop into a fatal severe bacterial infection. (1) The humanity lost hundreds of thousands of lives due to bacterial infection during World War I. However, the story changed radically with the invention of penicillin, which was called the magical shot or wonder drug at that time, and the subsequent invention of the rest of the antibiotics. For example, the mortality rate due to lower extremities wounds plummeted from 7.7 percent during World War I to around two percent during World War II, in part as a result of using penicillin. ${ }^{1}$ Nevertheless, the positive impact of penicillin on suppressing the 
spread of the bacteria infections did not last long due to the rapid appearance of bacterial resistance against the known antibiotics. ${ }^{2}$

In the beginning, antimicrobial resistance occurs when microorganisms such as fungi, parasites, viruses, and bacteria develop immunity against the commonly utilized antimicrobial medications such as antifungal, anthelmintic, antiviral, and the antibiotic medications. Therefore, antibiotic resistance can be described as the capability of bacteria to flourish and multiply even in the presence of medications that are considered to have the capacity to kill the bacteria, or at least, halt the reproduction of the bacteria. $^{3}$

Infections by a variety of resistant microbial infections such as bacterial, viral, or fungal are have an intimate hazard to the human life and wellbeing. ${ }^{2}$ Yet, at this time, the antibiotic-resistant bacteria are perceived to be the biggest challenge due to the extremely high mortality rate imposed by the antibiotic-resistant infections, and the subsequent health and economic burden. ${ }^{3}$ As the antibiotic medications lose their therapeutic efficacy, the anti-bacterial resistant infections are expected to spread more fiercely within the various communities and the risk of death, from what is currently labeled as a minor bacterial infection, will become extremely elevated. The treatment protocols for the multidrug-resistantbacterial infections includes hospitalization for long periods and the use of the latest generations of the broad-spectrum antibiotics - which are many folds more expensive than the traditional antibiotics, and are usually associated with more side effects. $^{2}$ Therefore, the specialized clinicians believe that the dissemination of antibiotic-resistant bacterial infections in a certain community will enormously impact the economy and the health facilities in 
that country ${ }^{4 \& 5}$ For instance, the additional healthcare expenses due resistant bacterial infections are more than 20 billion USD in the US, whereas the additional healthcare expenses within the EU countries is expected to be more than $1.6 €$ billion 6-8. Therefore, this review article will principally be focused on the influence of antibiotic misuse in the development of antibiotic-resistant bacterial infections and its negative impacts on the health of the general public.

The "American Centers for Disease Control and Prevention" (CDC), in 2013, published its first report concerning the hazards of antibioticresistant bacterial infections in the United States (U.S.), which involved a synopsis of the economic and health burdens of the most important antibiotic-resistant bacteria such as Methicillin-Resistant Staphylococcus Aureus (MRSA ), Escherichia coli, Clostridium difficile, and
Carbapenem-Resistant Acinetobacter. The approximate estimates for the CDC's 2013 report showed that no less than two million Americans acquired antibiotic-resistant bacterial infections, and no less than 23,000 annually reported deaths due to antibiotic-resistant bacterial infections. ${ }^{9}$ The intimate danger was sensed more intensely, in 2019, when the "American Centers for Disease Control and Prevention" (CDC) released its second report on the hazards of antibiotic-resistant bacterial infections in the United States (U.S.). As stated by the $2^{\text {nd }} C D C$ 's report, the yearly incidents of the antibioticresistant bacterial infections in the U.S. magnified by more than $35 \%$, from 2 million in 2013 to 2.8 million. Whereas, the number of deaths elevated by 12 thousand cases. ${ }^{3}$

In addition to the warnings of the CDC and the European Center for Disease Prevention, the World Health Organization (WHO) has shown in 
many occasions that there is compiling evidence of constant increase in the numbers of bacterial infections that are resistant to the currently available antibiotics. Each of these specialized agencies has demonstrated, beyond any doubt, that bacterial resistance to antibiotics is a tangible risk to human health. Indeed, the World Health Organization (WHO) has predicted century. Consequently, this leaves the healthcare professionals with very limited options if we considered the treatment of patients with resistant bacterial infections.

In Iraq, the exceptional circumstances that the country has experienced over the past four decades have greatly affected the absence of accurate studies assessing the extent of misuse of antibiotics and the prevalence of bacteria resistant to antibiotics. If we take into consideration the low extent of authorian monitory in various life aspects-including that related to the restriction of dispensing the antibiotics that, by 2050, 10,000,000 people will die, annually, due to the development of bacterial resistance to the commercially available antibiotics ${ }^{10-}$ 13. To make matters even worse, the number of invented antibiotics in the last two decades is the lowest since the invention of penicillin in the first quarter of the last

without prescription. Therefore, we could assume that the apparent part of the problem of resistant bacteria in Iraq is only the tip of the iceberg. For instance, in the city of Mosul, the Médecins Sans Frontières (MSF) stated that more than $90 \%$ of the patients who were admitted to one of its centers, due to bacterial infections, were found to be suffering from infection due to a multidrug-resistant microorganism(s). ${ }^{14}$

One of the main reasons for the emergence of bacterial strains resistant to the commercially available antibiotics is the unjustified use of 
antibiotics and self-medication with antibiotics (SMA). ${ }^{15}$ With regard to the unjustified use of antibiotics, many doctors tend to over-prescribe the antibiotics without a valid medical reason but rather in response to the patient demand. ${ }^{16}$ Additionally, the lack of adherence to the Iraqi Law of Pharmacy Practice of 1970 and the dispensing of the antibiotics to the layman without a prescription magnifies the abuse of antibiotics, and accelerates the emergence of antibiotic-resistant bacteria. ${ }^{17}$ On the other side of the equation, the public has a great role to play in the emergence of resistant bacteria by not adhering to the instructions of the physician and pharmacist regarding the method of taking antibiotics correctly. For instance, many patients do not adhere to the specified period of antibiotic treatment, and usually stop taking the antibiotic as soon as they feel better. In addition, another group of the patients do not adhere to the proper number of times it is necessary to take the antibiotic per day, or it may replace the antibiotic after only two or three days because they feel their health condition does not improve rapidly. ${ }^{18}$ To sum up, the main causes for the development of the bacterial resistance are attributed to several factors and as shown below 
- The excessive clinical use, and the irrational prescribing of the antibiotics by the physicians.

- The practice of self-medication among the patients suffering from general symptoms such as fever or cough.

- The poor compliance of the patients with the instructions of the prescribing doctors and the dispensing pharmacist.

- The Iraqi pharmaceutical market is not free from counterfeit and poorquality antibiotics.

After the discussion of the negative consequences of the ability of bacteria to develop resistance against the commercially available antibiotics, and the subsequent negative effects on the health and economy. Along with the most important reasons for accelerating the emergence of resistant bacteria. Let us now summarize the most important measures to be followed, both at the national and personal levels, to reduce the emergence and spread of antibioticresistant bacteria, as shown below:

\section{A- At the national level:}

- Implementation of an "Antibiotic Stewardship Program" to monitor antibiotic prescription the by doctors. In addition, implementing training courses for the healthcare providers concerning the rational use of antibiotics. ${ }^{19}$ 
- Activating the Iraqi Law of Pharmacy Practice for 1970, especially the aspect that is related to the prohibition of dispensing the antibiotics without a prescription.

- Spreading health awareness among community. This is can be achieved via conducting awareness campaigns, for example by the Iraqi Ministry of Health, about the dangers of practicing the self-medication with the antibiotics and the possible consequences of accelerating the emergence of resistant bacterial strains.

- Appropriate hospital infection control may minimize the spread of nosocomial antibiotic-resistant bacteria.

\section{B- At the Personal level:}

- Adhere to the advice of your doctor and pharmacist regarding the use of antibiotics.

- Do not use antibiotics without a proper prescription to avoid the emergence of resistant bacterial strains.
- Maintain the sanitation and personal hygiene, such as ensuring regular handwashing with soap to reduce the spread of the antibiotic-resistant bacteria.

\section{Conclusion}

To conclude, the rapid emergence of antibiotic-resistant bacteria threatens the astonishing health gains that have been attained since the invention of the antibiotic medications. From one side, the number of newly invented antibiotics over the last 20 years is very limited and did not cope with big challenge rapid emergence of antibiotic-resistant bacteria. On the other hand, the misuse and the overuse of antibiotics, world-widely, is transforming the antibiotic-resistant bacteria into a global health crisis. The government have to implement newfangled policies to confront this crisis-particularly, the antibiotic stewardship program. The general public's contribution as an involved participant to the development of the 
antibiotic-resistance crisis needs to be solved via appropriate awareness

\section{References:}

1. Dougherty PJ, Carter PR, Seligson D, Benson DR, Purvis JM. Orthopaedic surgery advances resulting from World War II. JBJS. 2004 Jan 1;86(1):176-81.

2. Fair RJ, Tor Y. Antibiotics and bacterial resistance in the $21 \mathrm{st}$ century. Perspectives in medicinal chemistry. 2014 Jan;6:PMC-S14459.

3. Centres for Disease Control and Prevention (US). Antibiotic resistance threats in the United States, 2019. Centres for Disease Control and Prevention, US Department of Health and Human Services; 2019.

4. Shrestha P, Cooper BS, Coast J, et al. Enumerating the economic cost of antimicrobial resistance per antibiotic consumed to projects about this extremely important public health problem.

inform the evaluation of interventions affecting their use. Antimicrob Resist Infect Control. 2018; 7(1): 98. doi:10.1186/s13756-018-03843

5. Naylor NR, Atun R, Zhu N, Kulasabanathan K, Silva S, Chatterjee A, et al. Estimating the burden of antimicrobial resistance: a systematic literature review. Antimicrob Resist Infect Control. 2018; 7:58. doi: 10.1186/s13756-0180336-y.

6. Centres for Disease Control and Prevention (US). World Health Day: Media Fact Sheet 2007.

7. The Wall Street Journal. FDA Chief Focuses on Antibiotic ResistanceAvailable 2019. at: http://online.wsj.com/article/ 
$\underline{\text { SB10001424052748703735804 }}$

575536411612671060.html.

8. European Medicine Agency The bacterial challenge: time to react. A call to narrow the gap between multidrug-resistant bacteria in the EU and the development of new antibacterial agents. [Accessed March 23, 2020]. Available at: http://www.ema.europa.eu/docs /en_GB/document_library/Rep ort/2009/11/WC500008770.pdf

9. Centres for Disease Control and Prevention (US). Antibiotic resistance threats in the United States, 2013. Centres for Disease Control and Prevention, US Department of Health and Human Services; 2013.

10. European Centre for Disease Prevention and Control. Proposals for draft EU guidelines on the prudent use of antimicrobials in human medicine. 2016.
11. Department of Health, Department for Environment Food and Rural Affairs. UK Five Year Antimicrobial Resistance Strategy 2013 to 2018 [Internet]. 2013. Available from:

https://www.gov.uk/governmen t/uploads/system/uploads/attach ment_data/file/244058/2013090 2_UK_5_year_AMR_strategy. pdf

12. The AMR Review. Tackling Drug-Resistant Infections

Globally: Final Report and Recommendations the Review on Antimicrobial Resistance [Internet]. 2016. Available from: https://amrreview.org/Publications

13. Department of Health. Reducing infections in the NHS [Internet]. 2016 [cited 2017 Jun 19]. Available from: https://www.gov.uk/governmen t/news/reducing-infections-inthe-nhs 
14. The invisible burden of antibiotic resistance in Mosul: Iraq: MSF [Internet]. Médecins Sans Frontières (MSF) International. 2019 .Available from:

https://www.msf.org/invisibleburden-antibiotic-resistancemosul-iraq

15. Rather IA, Kim BC, Bajpai VK, Park YH. Self-medication and antibiotic resistance: Crisis, current challenges, and prevention. Saudi journal of biological sciences. 2017 ; 1;24(4): 808-12.

16. Saleh N, Awada S, Awwad R, Jibai S, Arfoul C, Zaiter L, Dib W, Salameh P. Evaluation of antibiotic prescription in the Lebanese community: a pilot study. Infection ecology \& epidemiology. 2015 Jan 1;5(1): 27094.
17. Lansang MA, Lucas-Aquino R, Tupasi TE, Mina VS, Salazar LS, Juban N, Limjoco TT, Nisperos LE, Kunin CM. Purchase of antibiotics without prescription in Manila, the Philippines. Inappropriate choices and doses. Journal of clinical epidemiology. 1990; 1;43(1): 61-7.

18. Piddock L, Garneau-Tsodikova S, Garner C. Ask the experts: how to curb antibiotic resistance and plug the antibiotics gap?. Future medicinal chemistry. 2016 ;8(10):1027-32.

19. Nagel JL, Kaye KS, LaPlante KL, Pogue JM. Antimicrobial stewardship for the infection control practitioner. Infectious Disease Clinics. 2016; 30(3) : 771-84. 